\title{
Pengaruh Praktik Citizen Journalism terhadap Pemenuhan Kebutuhan Informasi Masyarakat Pada Akun Instagram@JKTINFO di Jakarta
}

\author{
Ryo, Farid Rusdi \\ ryo.915160213@stu.untar.ac.id,farid@fikom.untar.ac.id
}

Fakultas Ilmu Komunikasi Universitas Tarumanagara

\begin{abstract}
In a digital era where message exchange so fast, people can get national and foreign information and news. Current information dissemination uses social media. The social media that is very popular today is Instagram.The @Jktinfo account carries out the practice of citizen journalism which has been trusted as a credible media based on information content in the Jakarta city area. The author wants to examine the effect of citizen journalism practices on meeting the information needs of the public on the@Jktinfo Instagram account in Jakarta. The purpose of this study was to see the effect of citizen journalism practices on online media@Jktinfo on meeting the information needs of the community.The theories used in this research are new media theory, social media, citizen journalism, usability and satisfaction theory, and information needs. This research is a quantitative method. Nonprobability sampling technique with the type of convenience sampling technique. Collecting data in this study using a questionnaire to 150 respondents who are followers of the@jktinfo account and become citizen journalism in the Jakarta area. The results showed that citizen journalism has a significant influence on fulfilling the information needs of the public in Jakarta.
\end{abstract}

Keywords: citizen journalism, information needs fulfillment, social media

\begin{abstract}
Abstrak
Di era yang serba digital di mana pertukaran pesan terjadi begitu cepat, masyarakat dapat memperoleh informasi dan berita nasional maupun mancanegara. Penyebaran informasi saat ini menggunakan media sosial. Media sosial yang sangat populer saat ini adalah Instagram. Akun@Jktinfo melakukan praktik jurnalisme warga yang telah dipercaya sebagai media yang kredibel dengan berbasis konten informasi di wilayah kota Jakarta. Penulis ingin meneliti pengaruh praktik jurnalisme warga terhadap pemenuhan kebutuhan informasi masyarakat pada akun Instagram @Jktinfo di Jakarta. Tujuan penelitian ini adalah untuk melihat pengaruh praktik jurnalisme warga pada media online @Jktinfo terhadap pemenuhan kebutuhan informasi masyarakat. Teori yang digunakan dalam penelitian ini yaitu teori media baru, media sosial, jurnalisme warga, teori kegunaan dan kepuasan, dan kebutuhan informasi. Penelitian ini adalah metode kuantitatif. Teknik nonprobability sampling dengan jenis teknik pemilihan sampel secara convenience. Pengumpulan data pada penelitian ini menggunakan kuesioner kepada 150 responden yang merupakan pengikut dari akun @jktinfo dan menjadi citizen journalism di wilayah Jakarta. Hasil penelitian menunjukkan bahwa citizen journalism memiliki pengaruh signifikan terhadap pemenuhan kebutuhan informasi masyarakat di Jakarta.
\end{abstract}

Kata Kunci: jurnalisme warga, media sosial, pemenuhan kebutuhan informasi 
Ryo, Farid Rusdi: Pengaruh Kritik Citizen Journalism terhadap Pemenuhan Kebutuhan Informasi Masyarakat Pada Akun Instagram @JKTINFO Di Jakarta

\section{Pendahuluan}

Hidup di era yang serba digital dimana pertukaran pesan terjadi begitu cepat, komunikasi menjadi kunci utama dalam penyelesaian berbagai permasalahan. Seiring dengan perkembangan zaman, cara berkomunikasi diperluas melalui berbagai macam media, salah satu nya adalah media massa. Media massa mempunyai cabang yang sangat luas dengan ada nya internet. Melalui berbagai macam model, masyarakat memperoleh informasi dan berita nasional maupun mancanegara. Perubahan ini membuat pertukaran pesan sangat mudah dilakukan oleh siapapun dan kapanpun. Kemudahan mendapatkan informasi mempunyai dampak yang baik dan buruk kepada kehidupan sosial. Dampak positif nya adalah penyebaran informasi dapat dilakukan secara real time dan bisa disebarkan oleh siapa saja, namun hal ini menyebabkan kabar bohong juga sangat mudah untuk disebarkan oleh oknum-oknum yang tidak bertanggung jawab. Penyebaran informasi yang sangat ramai digunakan sekarang adalah media sosial. Melalui media sosial kita dapat mengakses beragam informasi mulai dari yang personal hingga pengetahuan umum. Media sosial yang sangat populer beberapa tahun kebelakang adalah instagram.

Melalui instagram, masyarakat juga bisa mendapatkan dan membagikan berita dengan kebutuhan masing-masing sesuai akun instagram yang diikuti. Misalnya, pengguna ingin mengetahui atau membagikan informasi mengenai suatu kota tertentu, maka pengguna dapat mengikuti akun khusus tersebut. Pada instagram masyarakat dapat menjadi penyebar sebuah berita dari warga dan untuk warga. Salah satu akun yang dapat menyebarkan informasi tersebut yaitu akun instagram @.Jktinfo.

Akun@Jktinfo adalah akun instagram yang menyajikan segala informasi seputar kota Jakarta. Adanya akun@Jktinfo masyarakat dapat memberikan informasi apapun yang sedang terjadi di kota Jakarta dengan mudah. Mulai dari informasi banjir, kecelakaan, kebakaran, cuaca, kuliner hingga politik. Informasi yang lengkap menarik pengguna media sosial untuk mengkuti akun@Jktinfo.@Jktinfo memiliki beberapa karakteristik seperti masyarakat mendapatkan suatu informasi dengan cepat, mudah, kapanpun dan dimanapun. @Jktinfo telah membawa masyarakat kedalam ruang yang dapat saling berinteraksi dan saling bertukar informasi. @.Jktinfo mempunyai beberapa konten yang dibutuhkan oleh pengguna nya, sehingga bisa memenuhi kebutuhan informasi masyarakat tersebut. Akun@JKTinfo pertama kali didirikan oleh Willy Jonathan dan berbasiskan media twitter, berdiri sejak tahun 2011 dan hingga sekarang sudah memiliki admin yang melaksanakan tugas kurasi berita dan upload 24 jam. Penulis tertarik untuk meneliti akun ini karena penulis merasa bahwa akun tersebut merupakan representasi media daring yang eksis dan mempunyai potensi dalam bidang komunikasi massa. Willy Jonathan selaku founder akun@JKTinfo dalam wawancara Tonight Show NET TV pada 17 Desember 2013.

Kebutuhan informasi adalah sesuatu yang sebaiknya dimiliki seseorang dalam melakukan pekerjaan penelitian, pendidikan, dan juga sebagai hiburan. Kemajuan teknologi menekan persaingan ketat antar bisnis media. Hal ini disebabkan karena masyarakat mulai meninggalkan media mainstream dan beralih ke new media yaitu media sosial. Orang tidak lagi menyalakan televisi untuk mengetahui kabar terbaru mengenai suatu kejadian, melainkan mereka berselancar di internet untuk mendapatkan informasi terkini dari media sosial. Keunggulan utama media sosial adalah informasi yang didapatkan bisa berasal dari orang sekitar yang 
melihat langsung dan penyebaran informasi tersebut lebih mudah diakses ketimbang harus menunggu acara televisi. Metode ini memperluas dunia jurnalistik dan sering dikenal dengan sebutan jurnalisme warga atau citizen journalism. Banyaknya masyarakat yang membutuhkan informasi secara real time oleh karena itu citizen journalism mempunyai peran yang sangat penting (Laloo, 2002:12)

\section{a. New Media (Media Baru)}

New media adalah media yang menggunakan internet, media online berbasis teknologi, berkarakter fleksibel, berpotensi interaktif dan berfungsi secara pribadi maupun publik. Media baru tidak hanya menyatukan perbedaan pada beberapa media. Karakter yang berbentuk digital, memudahkan dalam berkomunikasi dan untuk bertukar informasi. Media baru lebih memiliki interaksi antara komunikator dengan komunikannya lebih bebas berkomunikasi dan berinteraksi. Dalam media konvensional, komunikasi yang terjadi adalah komunikasi satu arah dimana tidak terdapat interaksi antara media pembuat berita dengan pendengarnya, namun pada media atau new media, komunikasi dapat terjadi secara dua bahkan tiga arah antara media, pendengar dan penyebar. Pada media baru, komunikasi dijembantani oleh fitur komentar, dengan ada nya fitur komentar, memungkinkan adanya interaksi antar komunikator dan komunikan.

\section{b. Media Sosial}

Media sosial adalah platform online yang bisa dengan mudah digunakan untuk partisipasi, berbagi dan menciptakan konten. Contohnya blog, jejaring sosial, dan dunia virtual. Media sosial yang populer saat ini adalah Instagram. Instagram merupakan aplikasi jejaring sosial yang berbasis foto dan tulisan. Hal ini membuat kita tidak hanya membaca, melainkan dapat melihat gambaran dari unggahan seseorang. Dengan kemajuan teknologi, instagram dimanfaatkan dengan berbagai macam tujuan. Salah satunya adalah pemenuhan kebutuhan informasi. Dengan adanya visual, membuat orang dapat mempercayai suatu peristiwa karena adanya bukti pendukung seperti foto dan video.

\section{c. Citizen Journalism}

Menurut Nugraha (2012:18), citizen journalism adalah masyarakat biasa yang berpengalaman sebagai seorang wartawan profesional yang mempunyai peralatan teknologi sehingga dapat meliput, mengumpulkan, menulis, dan menyebarkan di media online mengenai peristiwa yang terjadi di sekitarnya karena mendapatkan berbagai semangat dari pembaca lainnya. Dengan bantuan media online di media sosial, penyebaran informasi terjadi sangat cepat dan dapat diakses oleh pengguna media sosial lainnya. Dalam citizen journalism siapapun bebas berpendapat dan berekspresi dihadapan publik, karena berita citizen journalism adalah berita dari masyarakat, oleh masyarakat dan untuk masyarakat. Berikut adalah beberapa indikator alat ukur citizen journalism:

1. Durasi: Pengukuran durasi mengakses media untuk menghitung berapa lama seseorang menghabiskan waktunya di suatu media (berapa jam dalam satu hari); atau berapa lama waktu yang dihabiskan seseorang untuk membaca berita Citizen Journalism.

2. Frekuensi: Frekuensi penggunaan media adalah kumpulan data - data mengenai seberapa sering sesorang mengakses berbagai jenis media. 
3. Atensi: Atensi merupakan hubungan antara khalayak dengan sebuah pesan yang disampaikan oleh media yang dapat menarik perhatian (attention). Menurut Rakhmat (2005:52), perhatian adalah proses kognitif ketika rangkaian stimuli menjadi menonjol dalam kesadaran lainnya melemah. Perhatian didaptkan apabila seseorang terfokus pada salah satu alat indera, dan tidak teralu merasakan indera lain.

\section{d. Teori Uses and Gratification}

Teori uses and gratification lebih menekankan pada pendekatan masyarakat dalam melihat media massa, yang artinya manusia mempunyai kebebasan dan wewenang untuk menentukan medianya. Pengguna media adalah orang yang aktif dalam proses komunikasi dan berusaha untuk mencari sumber media yang paling baik dalam memenuhi kebutuhannya. Teori uses and gratifications mengasumsikan bahwa pengguna mempunyai pilihan alternatif untuk memuaskan kebutuhannya. Masyarakat memiliki kebebasan untuk memutuskan bagaimana dan lewat media mana mereka menggunakan media dan dampak pada dirinya. Teori ini menjelaskan bagaimana pengguna media berusaha mencari media yang paling dipercaya untuk memenuhi kebutuhannya, salah satunya yaitu memenuhi kebutuhan informasi (Nurudin, 2003:181).

Menurut Syaffril (2004:18-19) terdapat empat kategori pendekatan informasi, yaitu:

1. Current need approach: pengguna media mencari informasi untuk memperbanyak pengetahuan.

2. Everyday need approach: pengguna membutuhkan informasi secara cepat, mendalam, dan sering.

3. Exhaust need approach: pengguna bergantung terhadap informasi yang ia dapatkan.

4. Catching-up need approach: pengguna mencari perkembangan paling baru yang sesuai dengan kebutuhannya.

Penulis ingin meneliti apakah pengaruh praktik citizen journalism dapat mempengaruhi pemenuhan kebutuhan informasi masyarakat pada akun instagram @jktinfo di Jakarta.

\section{Metode Penelitian}

Penelitian ini menggunakan metode kuantitatif. Populasi dalam penelitian ini adalah followers dari akun @jktinfo. Sampel yang digunakan dalam penelitian ini adalah followers atau masyarakat yang mengikuti akun@jktinfo dan menjadi citizen journalism di wilayah Jakarta dengan menggunakan non probabilty sampling yaitu teknik yang setiap populasinya tidak memberi kesempatan yang sama untuk dijadikan sebagai sampel (Sugiyono, 2015:84) dan teknik pemilihan sampel yang digunakan adalah secara convenience sampling yang artinya pengambilan sampel yang didasarkan pada ketersediaan elemen populasi yang mudah diperoleh dan kemudahan untuk dijangkau, maka itulah yang nantinya akan dijadikan sampel.

Pengambilan sampel dilakukan dengan menyebarkan kuesioner secara online menggunakan google form. Responden yang berhasil dikumpulkan sebanyak 150 responden dari followers atau masyarakat yang mengikuti akun@jktinfo dan menjadi citizen journalism di wilayah Jakarta. Pada penelitian ini, variabel diukur menggunakan skala likert dengan bobot sebanyak 5 poin. Angka 1 menunjukkan 
sangat tidak setuju (STS) dan angka 5 menunjukkan sangat setuju (SS). Penelitian ini melakukan teknik pengolahan dan analisis data dengan uji Outer Model (Model Pengukuran) dan Inner Model (Model Struktural) yaitu:

a. Koefisien Determinasi $\left(\mathrm{R}^{2}\right)$ digunakan untuk menjelaskan pengaruh variabel $\mathrm{x}$ terhadap variabel $\mathrm{y}$. Nilai R-Square 0,75 dinyatakan sebagai model yang kuat, 0,50 sebagai model moderate, dan jika hasil R-Squares hanya 0,25 atau kurang dari 0,25 model dikatakan lemah.

b. Effect Size $\left(\mathrm{f}^{2}\right)$ digunakan untuk melihat apakah pengukuran variabel independen terhadap variabel dependen memiliki pengaruh yang substantif dengan cara mengukur effect size. Jika nilai $f^{2} 0,02$ maka memiliki pengaruh kecil, nilai 0,15 maka memiliki pengaruh moderat, dan nilai 0,35 memiliki pengaruh besar pada level struktural (Ghozali, 2014:78)

c. Predictive relevance $\left(\mathrm{Q}^{2}\right)$ dilakukan untuk mengukur seberapa baik nilai observasi yang di hasilkan oleh variabel atau model dan estimasi parameternya. Menurut Ghozali (2014:79), Jika nilai Q2 lebih besar dari 0 (Q2>0) maka hasil menunjukkan bahwa model mempunyai predictive relevance, sedangkan jika nilai Q2 kurang dari $0(\mathrm{Q} 2<0)$ maka hasil menyatakan model tidak memiliki predictive relevance.

d. Goodness of fit index (GoF) dilakukan untuk mengevaluasi model inner dan model outer dan juga untuk menyediakan pengukuran sederhana secara keseluruhan dari prediksi model menurut Ghozali (2014:82). Nilai Gof yang baik adalah antara 0 s.d 1 dengan nilai yang direkomendasikan 0,50 (dekat dengan 1). Maka dengan kesimpulan nilai 0,10 termasuk dalam tingkat Gof kecil, nilai 0,25 termasuk dalam tingkat Gof medium, dan nilai 0,36 termasuk Gof besar.

e. Pengujian Hipotesis. Nilai probabilitas untuk hubungan variabel independent terhadap variabel dependen dalam model pengukuran harus signifikan. Tingkat signifikansi dinilai menggunakan metode bootstrapping. Hipotesis diterima jika nilai probabilitas $(p$-value) di bawah $0,05(\mathrm{p}<0,05)$.

\section{Hasil Temuan dan Diskusi}

Nilai outer loadings (loading faktor) dan nilai average variance extracted (AVE) sudah memenuhi kriteria convergent validity karena memiliki outer loadings (loading faktor) di atas 0,70 dan nilai average variance extracted (AVE) diatas 0,50. Dapat disimpulkan bahwa indikator atau pernyataan di dalam kuisioner tersebut mampu mewakili semua yang diukur oleh penelitian melalui kuisioner dan telah memenuhi convergent validity atau valid dan begitu juga dengan nilai cross-loadings pada discriminant validity. Pada hasil uji reliabilitas semua nilai composite reliability $>0.70$ yang artinya bahwa pengujian dinyatakan valid atau mempunyai reliabilitas yang tinggi.

Tabel 1. Nilai Outer Loadings

\begin{tabular}{|c|c|c|}
\hline & Outer Loadings & Keterangan \\
\hline CJ1 & 0,719 & Valid \\
\hline CJ4 & 0,762 & Valid \\
\hline CJ5 & 0,717 & Valid \\
\hline CJ6 & 0,720 & Valid \\
\hline
\end{tabular}


Ryo, Farid Rusdi: Pengaruh Kritik Citizen Journalism terhadap Pemenuhan Kebutuhan Informasi Masyarakat Pada Akun Instagram @JKTINFO Di Jakarta

\begin{tabular}{|l|c|c|}
\hline PKI1 & 0,897 & Valid \\
\hline PK11 & 0,706 & Valid \\
\hline
\end{tabular}

Sumber: Hasil Pengolahan data dengan SmartPLS 3.

Tabel 2. Nilai Average Variance Extracted (AVE)

\begin{tabular}{|c|c|c|}
\hline & Average Variance Extracted (AVE) & Keterangan \\
\hline $\mathrm{X}$ & 0,533 & Valid \\
\hline $\mathrm{Y}$ & 0,651 & Valid \\
\hline
\end{tabular}

Sumber: Hasil Pengolahan data dengan SmartPLS 3.0

Tabel 3. Hasil Uji Reliabilitas

\begin{tabular}{|c|c|c|}
\hline Variabel & Composite Reliability & Keterangan \\
\hline Citizen Journalism (X) & 0,820 & Reliabel \\
\hline $\begin{array}{c}\text { Pemenuhan Kebutuhan } \\
\text { Informasi (Y) }\end{array}$ & 0,786 & Reliabel \\
\hline
\end{tabular}

Sumber: Hasil Pengolahan data dengan SmartPLS 3.0

Tabel 4. Hasil Nilai $\mathrm{R}^{2}$

\begin{tabular}{|c|c|c|}
\hline Variabel & R-square & $\begin{array}{c}\text { R-square } \\
\text { Adjusted }\end{array}$ \\
\hline $\begin{array}{c}\text { Pemenuhan Kebutuhan } \\
\text { Informasi (Y) }\end{array}$ & 0,397 & 0,393 \\
\hline
\end{tabular}

Sumber: Hasil Pengolahan data dengan SmartPLS 3.0

Nilai $R$-square yang diperoleh adalah sebesar 0,393, sehingga pengaruh variabel citizen journalism terhadap variabel pemenuhan kebutuhan informasi masyarakat pada akun instagram @Jktinfo di Jakarta sebesar 39,3\% sedangkan sisanya $60,7 \%$ dipengaruhi oleh faktor-faktor lain yang tidak dijelaskan dalam penelitian ini. Hal ini dapat disimpulkan bahwa pengaruh model variabel independen terhadap variabel dependen memiliki pengaruh yang moderat.

Tabel 5. Hasil Uji Effect Size $\left(\mathrm{f}^{2}\right)$

\begin{tabular}{|c|c|}
\hline Variabel & Nilai Effect Size (f2) \\
\hline Citizen Journalism (X) & 0,659 \\
\hline
\end{tabular}

Sumber: Hasil pengolahan data dengan SmartPLS 3.0

Pengaruh variabel independen yaitu Citizen Journalism (X) terhadap variabel dependen yaitu Pemenuhan Kebutuhan Informasi memiliki pengaruh yang besar dengan nilai 0,659 .

Tabel 6. Hasil Uji Predictive Relevance $\left(\mathrm{Q}^{2}\right)$

\begin{tabular}{|c|c|}
\hline Variabel & $\begin{array}{c}\text { Nilai Predictive } \\
\text { Relevance (f2) }\end{array}$ \\
\hline $\begin{array}{c}\text { Pemenuhan Kebutuhan } \\
\text { Informasi (Y) }\end{array}$ & 0,233 \\
\hline
\end{tabular}

Sumber: Hasil pengolahan data dengan SmartPLS 3.0 
Nilai predictive relevance $(\mathrm{Q})$ yang diperoleh adalah sebesar 0,233 . Sehingga dapat disimpulkan bahwa, nilai observasi yang dihasilkan oleh variabel atau model adalah baik dan memiliki predictive relevance karena nilai $\mathrm{Q}$ lebih besar dari 0 $(\mathrm{Q}>0)$.

Hasil perhitungan nilai $\overline{\mathrm{GoF}}$ dilakukan secara manual dengan rumus: $\mathrm{GoF}=\sqrt{ }$ AVE x R ${ }^{2}$. Berdasarkan hasil perhitungan diperoleh nilai goodness of fit index (Gof) diperoleh sebesar 0,482. Sehingga dapat disimpulkan bahwa model penelitian yang digunakan mempunyai kecocokan baik dan termasuk kedalam tingkat goodness of fit index (Gof) yang besar.

Tabel 7. Hasil Pengujian Hipotesis

\begin{tabular}{|c|c|c|c|c|c|}
\hline & Hipotesis & $\begin{array}{c}\text { Original } \\
\text { Sample }\end{array}$ & $\begin{array}{c}\text { T- } \\
\text { statistik }\end{array}$ & $\begin{array}{c}\text { P- } \\
\text { value }\end{array}$ & Keterangan \\
\hline H1 & $\begin{array}{c}\text { Citizen Journalism - } \\
\text { P Pemenuhan } \\
\text { Kebutuhan Informasi }\end{array}$ & 0,630 & 10,718 & 0,000 & Signifikan \\
\hline
\end{tabular}

Sumber: Hasil pengolahan data dengan SmartPLS 3.0

Hasil yang diperoleh dari pengujian hipotesis di atas dengan melihat besarnya nilai $p$-value $(<0,05)$ menunjukkan nilai $p$-value sebesar 0,000 yang artinya sesuai dengan kriteria. Hal ini menunjukkan bahwa terdapat pengaruh positif dan signifikan citizen journalism terhadap pemenuhan kebutuhan informasi masyarakat. Yang dimaksud dengan pengaruh positif dan signifikan adalah adanya pengaruh secara bersamaan dan nyata antara variabel independen (citizen journalism) terhadap variabel dependen (pemenuhan kebutuhan informasi). Semakin banyak citizen journalism maka semakin terpenuhi pemenuhan kebutuhan informasi masyarakat secara nyata.

Berdasarkan hasil penelitian, menunjukkan bahwa praktik citizen journalism (X) mempunyai pengaruh terhadap pemenuhan kebutuhan informasi (Y), yaitu sesuai dengan hipotesis (Ha) peneliti. Dalam teori uses and gratification dijelaskan bahwa masyarakat sendiri yang memilih media mana yang ingin diakses, pada permasalahan ini yaitu Citizen journalism. Dalam kondisi dimana semua hal dipaksa melakukan digitalisasi, semua dibutuhkan secara cepat termasuk dengan informasi. Kebutuhan informasi yang dibutuhkan pun sangat beragam mengingat berbagai macam audiens yang mengakses internet. Konsep uses and gratification mengacu pada khalayak yang aktif dalam memilih informasi yang diaksesnya, citizen journalism menjadi salah satu yang populer pada era digital ini. Dengan ada nya citizen journalism maka informasi dapat tersebar dengan cepat dan juga tidak membutuhkan jurnalis profesional untuk datang meliput. Dampak positif dalam pemenuhan kebutuhan informasi melalui citizen journalism adalah ketika ada suatu kejadian, banyak faktafakta lain yang dapat diungkapkan dari perspektif lain dam kemudahan mengakses berita mengenai suatu kejadian agar dapat cepat ditangani.

Jika masyarakat mendapatkan informasi yang sesuai dengan keinginan mereka, maka peran citizen journalism telah terlaksana secara baik. Dengan lengkapnya informasi yang diberikan kepada masyarakat, maka akan semakin banyak orang yang mengikuti isntagram @jktinfo untuk mendapatkan informasi ter update melalui saluran citizen journalism. Berdasarkan teori uses and gratification, followers Instagram@jktinfo memilih citizen journalism untuk memberikan dan mendapatkan informasi. 
Dengan adanya Instagram sebagai media baru masyarakat mendapatkan informasi, memudahkan setiap orang untuk mengakses akun-akun yang di buat untuk menyebarkan informasi terutama di bidang jurnalistik. @jktinfo membuat orang orang yang tinggal di jakarta dapat memberi dan menerima informasi seputar kota jakarta dan juga daerah-daerah spesifik ketika adanya suatu peristiwa atau informasi terbaru. Citizen journalism menjadi kunci untuk memberikan informasi kepada orang lain melalui media tersebut untuk memenuhi berbagai jenis kebutuhan yang ingin diketahui seseorang. Hal yang membuat citizen journalism di minati orang-orang adalah karena informasi yang diberikan netral dan tidak di lebih kurangkan karena tidak terikat pada media atau portal berita, juga dengan ada nya citizen journalism dapat membantu sesama masyarakat dalam menangani atau menghindari kesalahan.

\section{Simpulan}

Citizen journalism mempunyai peran yang sentral dalam pemenuhan kebutuhan informasi masyarakat, bisa dilihat dari data yang menunjukkan bahwa 39 persen orang yang mem-follow akun@Jktinfo mencari informasi melalui saluran citizen journalism. Dari data ini terbukti bahwa orang-orang membutuhkan informasi dari sesama warga mengenai tempat tinggal atau lokasi tertentu untuk memenuhi rasa puas akan kebutuhan informasi. Nilai tertinggi pada citizen journalism adalah karena informasi yang diberikan baru dan jelas. Jika dilihat dari kondisi pada tahun 2020 ini, memang masyarakat cenderung membutuhkan informasi yang baru karena perkembangan berita dan informasi sangat cepat dan berubah setiap harinya, kemudian informasi yang diberikan harus jelas karena jika tidak maka informasi tersebut dapat menjadi miskonsepsi terhadap cara penangan berbagai kasus. Dengan kata lain, berdasarkan hasil analisis data dari penelitian ini, maka dapat disimpukan bahwa terdapat pengaruh yang positif dan signifikan citizen journalism terhadap pemenuhan kebutuhan informasi masyarakat pada akun instagram@Jktinfo di Jakarta.

\section{Ucapan Terima Kasih}

Terimakasih kepada seluruh narasumber serta para responden penelitian atas kerjasama yang baik sehingga penulis mampu memberikan yang terbaik dan menyelesaikan penelitian ini hingga akhir.

\section{Daftar Pustaka}

Ghozali, Imam. (2014). Structural Equation Modeling, Metode Alternatif dengan Partial Least Square (PLS). (Edisi 4). Semarang: Badan Penerbit Universitas Diponegoro.

Ghozali, Imam dan Latan, Hengky. (2015). Partial Least Square Konsep Teknik dan Aplikasi Menggunakan Program SmartPLS 3.0. (2nd Edition). Semarang: Badan Penerbit Universitas Diponegoro.

Husein, Ananda Sabil. (2015). Penelitian Bisnis dan Manajemen Menggunakan Partial Least Squares (PLS) dengan smartPLS 3.0. Jakarta: Universitas Brawijaya, 18.

Laloo, Bikika Tariang. (2002). Information Needs, Information Seeking behaviour and Users. New Delhi: Ess Ess Publication. 
Nugraha, Pepih. (2012). Citizen Journalism: Pandangan, Pemahaman, dan Pengalaman. Jakarta: PT Kompas Media Nusantara.

Nurudin. (2003). Komunikasi Massa. Cespur: Malang.

Rakhmat, Jalaluddin (2005). Psikologi Komunikasi. Bandung: PT. Remaja Rosdakarya.

Sugiyono. (2015). Metode Penelitian Pendidikan (Pendekatan Kuantitatif, Kualitatif dan $R \& D)$. Bandung: CV. Alfabeta.

Syaffril, Muhammad. (2004). Perilaku Pencari Informasi Melalui Koleksi Surat Kabar Untuk Memenuhi Kebutuhan Informasi: Studi Deskriptif Tentang Perilaku Pencarian Informasi Melalui Koleksi Surat Kabar Untuk Memenuhi Kebutuhan Informasi Mahasiswa di Perpustakaan UNISBA. Universitas Islam Bandung. Skripsi: Tidak diterbitkan. 